\title{
Invisible diaspora: A scoping review of migrant caregivers' social integration trajectory
}

\author{
Original Research
}

Oona St-Amant ${ }^{1}$, Mandana Vahabi ${ }^{1,2}$, Josephine Pui-Hing Wong ${ }^{1,3,4}$, Bukola Salami ${ }^{5}$, Kenneth Po-Lun Fung ${ }^{6,7}$, Jovana Miholjcic ${ }^{8}$, Valerie $\operatorname{Tan}^{1}$

${ }^{1}$ Daphne Cockwell School of Nursing, Ryerson University, Ryerson University, Toronto, Ontario, Canada; ${ }^{2}$ ICES Central, Toronto, Ontario, Canada; ${ }^{3}$ Dalla Lana School of Public Health, University of Toronto, Toronto, Ontario, Canada; ${ }^{4}$ Graduate Program in Environmental Studies, York University, Toronto, Ontario, Canada; ${ }^{5}$ Faculty of Nursing, University of Alberta, Edmonton, Alberta, Canada; ${ }^{6}$ Asian Initiative in Mental Health, Toronto Western Hospital, University Health Network, Toronto, Ontario, Canada; ${ }^{7}$ Department of Psychiatry, University of Toronto, Toronto, Ontario, Canada; ${ }^{8}$ University Health Network, Toronto, Ontario, Canada

Corresponding author: O. St-Amant (ostamant@ryerson.ca)

\section{ABSTRACT}

Introduction: The Canadian Caregiver program, initiated in 1992, functions to conceal the inadequate public policy and programs on child and elder care in Canada. Consequently, migrant caregivers have become an invisible diaspora filling a domestic labour gap with few protections. Aim and Methods: This scoping review aims to identify the systemic barriers that undermine social integration of migrant caregivers. We searched ten publication index databases from 2001-2020. We retrieved 1,551 articles, after accounting for exclusion criteria, 22 peer-reviewed articles were selected for this review representing migrant women across Canada who are and/or were part of the program. Results: Four key barriers were identified: economic exploitation, deskilling and downward occupational mobility, asymmetrical accountability, and social isolation. Conclusion: Discriminatory policies and hidden exploitative employment practices of the Canadian Caregiver program perpetuate a cycle of marginalization. This review also found that community support groups and alliances function to promote resilience among migrant caregivers through community advocacy.

\section{KEYWORDS}

Social integration, migrant caregivers, Caregiver Program

\section{FUNDING SOURCE}

This work was funded by CIHR Knowledge Dissemination Grant from the Institute of Gender and Health.

\section{INTRODUCTION}

Modern day domestic care work is modelled after historical colonization, displacement, and minority marginalization practices (Castles \& Miller, 2009; Parrenas, 2012). Care work is gendered and racialized resulting in, exploitation, marginalization, and social exclusion of migrant caregivers (Cohen, 2000; D’Addario, 2013; Salami \& Nelson, 2014; Spitzer et al., 2009). Systemic racism has meant employers reduce workers to their preconceived racialized traits, rather than recognizing their skill and knowledge. For instance, compared to lighter skinned women, darker skinned women are often assigned the least desirable work (Bakan \& Stasiulis, 2012). This process can be observed in Canada's Caregiver Program where Filipino women are relegated to providing care for Canadian families in their homes (Callon, 2017). The Canadian Caregiver program, initiated in 1992, functions to divert attention from the lack of universal childcare and inadequate health and social care policies to designed to address the unmet needs of its growing elderly population (Atanackovic \& Bourgeault, 2014; Chowdhury \& Gutman, 2012). The program allows Canadians to hire highly educated and skilled temporary foreign workers for minimum 
wage. In a review of the literature, Spitzer et al. (2008) found that $90 \%$ of migrant caregivers accepted in the Caregiver Program are women, with the vast majority coming from the Philippines and a growing number from Haiti as well as African, Latin American, and Asian countries (Hanley, Larios, \& Koo, 2017). Most are highly skilled graduates from nursing and teaching, between the ages of 25-44 years (Kelly, Park, de Leon, \& Priest, 2011).

According to Tungohan (2013), migrant women face a growing challenge: they have limited economic power in their home countries which forces them to migrate in support of their families, and yet their ability to actively care for their own children is restricted by geographical distance. As a result, migrant women are forced to sustain transient, low wage employment in countries like Canada, deepening loss of identity and exploitation (Parrenas et al., 2015). Canadian governments created, and continue to reinforce, the international division of reproductive labour. Driven by a lack of affordable childcare and inadequate home care system, Canada initiated its migrant caregiver program in the early 1900s through recruitment of foreign domestic workers from Britain and Scandinavian countries. The Foreign Domestics Movement (FDM) was established in 1981 and served to further attract Caribbean women to domestic work in Canada (Tungohan, 2013). The program expanded in 1992 to become the Live-in Caregiver Program (LCP), which offered qualifying migrant caregivers a route to permanent residency after 24 months of work as caregivers. The main qualifications to migrate to Canada through the program is a minimum of one year education in a relevant field as well as experience. This Program was designed to meet a market need for qualified temporary foreign workers (TFWs) to care for children, older adults and people with disabilities while living in the employers' homes.

In February 2019, Immigration, Refugees and Citizenship Canada (IRCC) restructured the pathways to permanent residence as a caregiver. The current pathways are: 1) interim pathway for caregivers; 2) caring for children program; 3) caring for people with high medical needs program; and 4) live-in caregiver program. Changes to the program translate into a more elitist system of recruitment, with fewer opportunities for low-skilled workers, restricted access to permanent residency and emboldened employer participation. Hegemonic citizenship pathways designed to absolve the government from socially inclusive policy compound migrant caregivers' access to sustained resources. Because migrant caregivers enter as temporary foreign workers and are not eligible for permanent residency for the first two years, government programs are directed at settlement (short term) rather than integration. Meanwhile, migrant caregivers are expected to pay taxes and unemployment insurance without access to citizenship integration programs (Stasiulis \& Bakan, 2005). Migrant caregivers are put at a disadvantage to integrate into Canadian culture socially and inclusively when they are systemically excluded from protections and opportunities that would facilitate their integration (Cohen, 2000; Stasiulis \& Bakan, 2005; D’Addario, 2013; Spitzer et al., 2009). In the context of this article, social integration refers to equitable and sustained access to and participation in resources that support social and economic growth. This article presents data yielded from a scoping review that examines existing literature related to government policies that shape social integration for migrant caregivers in Canada.

\section{AIM AND METHODS}

A scoping review methodology was chosen to enhance our understanding of social integration for migrant caregivers in Canada. The framework proposed by Arksey and O'Malley (2005). This methodology was selected over other review designs, such as systematic review, because it permitted us to broadly explore a topic with limited knowledge. Unlike systematic reviews where the quality of studies is considered, scoping reviews are often described as a process of mapping and summarizing the breadth and depth of a field (Levac. Colqhuoun, \& O'Brien, 2010). Most importantly, scoping reviews allow for analytical (re)interpretation of the literature.

Arksey and O'Malley (2005) put forward five stages for conducting a scoping review, with a sixth optional stage. Stage 1 relates to identifying a research question, which should provide a breadth of coverage. We aim to examine what is known from existing Canadian literature about systemic barriers and facilitators of social integration among migrant caregivers? Stage 2 involves identifying relevant studies and developing a decision plan for searching the literature. We searched ten publication index databases: ProQuest Research Library, Sociology 
Collection, CINAHL, JSTOR, Social Science Citation Index, Google Scholar, ProQuest Dissertations and These Global, Migrant Workers Rights Global, CHHRN$\mathrm{CIHI}$ Library and EbscoHost spanning from January 1st, 2001-December 31st, 2020 to capture the latest literature. We included studies from the perspective of adult women who are current or former members of the migrant caregiver program in Canada. We used both primary and secondary source articles published in English (Table 1).

Books, reports, thesis work and academic articles were all included in this review. We used the following keywords: live-in caregiver program*, LCP*, federal caregiver program*, migrant/live-in/ home/ temporary caregivers*, migration and settlement*, social/ economic/ identity integration*, temporary status*, social mobility*, workers rights*, social exclusion*, marginalization*, vulnerability*, access*, health*, deskilling*, Canada*. Stage 3, study selection, includes the application of post hoc inclusion and exclusion criteria based on the research question and new familiarity with the literature. We made initial determinations of inclusion based on abstracts and titles (Figure 1).

The research team met on several occasions to discuss the literature and make decisions about which text met the inclusion criteria. We excluded studies that examined temporary foreign workers (broadly) as well as studies that exclusively looked at specific health outcomes for migrant caregivers. If there was uncertainty about inclusion, the authors discussed its relevance to the research questions and came to a collective decision. Stage 4 refers to data charting, in this case the authors extracted data into a chart using the following headings: citation, location (denoting a specific province), population characteristics, study design, aim of study, key findings and rationale for inclusion (Table 2). Stage 5 entails collating, summarizing, and reporting results. Our thematic analysis was both descriptively informed by numerical summary analysis (how often/much did a theme occur) as well as qualitative analysis (depth and richness of the theme). The findings yielded from this analysis serve the broader purpose to understand social integration and we were therefore attentive to nuance, power, and privilege.

\section{RESULTS}

The results of this review reveal a relative paucity of work on migrant caregiver social integration $(n=22)$. The research articles included in this study used either a qualitative or mixed-methods study design. Data collection spanned several Canadian provinces including Nova Scotia, Quebec, Ontario, Alberta, and British Columbia. Our analysis five themes emerged: economic exploitation, deskilling and downward occupational mobility, asymmetrical accountability, social isolation, and resilience. Table 2 describes each article included in the scoping review. We have further highlighted the major theme that emerged from the research article.

\section{Economic exploitation}

Economic exploitation was a recurrent and complex theme that emerged in this review. Several authors described inadequate pay with rates well below minimum wage (Banerjee et al., 2017; Bourgeault, Parpia \& Atanackovic, 2010; Chowdhury \& Gutman, 2012; PINAY, 2008). Most authors conceded that migrant caregivers were not paid an hourly wage but rather a weekly sum that was not commensurate with the number of worked hours (Gallerand, Gallie, and Gobeil, 2015; Oishi, 2008). In addition to low wages, Gallerand et al. (2015) found that two-thirds of Filipino caregivers included in their study $(n=33)$ immigrated via a third-party recruitment agency, while PINAY group (2008) reported 35\% $(n=148)$ of respondents used an agency. Despite this discrepancy, all but 3 studies included in this review remarked on perilous recruitment agencies for migrant caregivers. At best, these agencies were described as providing minimal formal assistance (Bonifacio, 2008) and at worse, provided illegal employment contracts with fake employers (Kapiga, 2009). Furthermore, many caregivers were tied to long-term debts to an employment agency with service fees estimated around $\$ 5000$ (Gallerand et al., $2015)$ to $\$ 25,000$ notwithstanding travel and accommodations (Salami, 2014). While some studies alluded to high remittance fees, there is a lack of data related to how much migrant caregivers spend on remittance. Estimates suggest that remittance costs average $9 \%$ in Canada (World Bank, 2014), although they can reach as high at $30 \%$ (Report on the Remittance Agenda of the G20, 2014).

\section{Deskilling and downward occupational mobility}


The Philippines was described as the top source country for migrant caregivers under the Caregiver Program in several studies (Bourgeault et al., 2010; Kapiga, 2009; Palmer, 2010; Salami, 2014; Salami \& Nelson, 2014). Filipino women are often revered as 'national heroes' by local government to encourage outward mobility and local prosperity through remittance (Bourgeault et al., 2010). The majority of migrant caregivers are highly educated. Bourgeault et al. (2010) found $53 \%$ of migrant caregivers entering through the Caregiver Program had a bachelor's degree and professional nurses (37\%) were overrepresented in domestic work. Kapiga (2009) found $77 \%$ of migrant caregivers were university educated and Miller (2010) found that $60 \%$ of migrant caregivers in her sample had post-secondary education in the fields of nursing, education, or midwifery. However, professional development for these highly skilled migrant caregivers were truncated (Banerjee et al., 2017). Oishi (2008) describes how many migrant caregivers lose their skills when they are removed from their professional practice; further courses to upgrade skills are very costly for foreign residents. Notably, Oishi also describes how many migrant caregivers turn to informal care work when they lose their self-esteem and self-confidence to practice in their designated field. Bourgeault et al. (2010) notes that while skilled workers are more likely to be selected for the program because of their credentials, they in turn become deskilled in the process, at least temporarily when they are unable to work within their scope of practice. For example, when a Registered Nurse is hired as a migrant caregiver and unable to practice their skills.

Salami and Nelson (2014) critically discuss migration through the Caregiver Program as part of the global care chain, whereby they apply Hochschild's (2002) concept of emotional imperialism which delves into emotional care work that is extracted from the Global South to service the Global North. In their discussion, they note a labour gap that is left in Global South, typically filled by older daughters and mothers, structured by gender, class, nationality and ethnicity. The authors illuminate the downward occupational mobility of migrant caregivers who are required to work a minimum of 24 months in the Caregiver Program before they are eligible to seek employment in their trained profession (Salami, 2016; Salami \& Nelson, 2014).
Oishi (2008) describes how many migrant caregivers are recruited to Canada to fill care deficits in the healthcare system but end up being overqualified and working in low-skill work because degrees and training are not recognized in Canada. The downward mobility is further sustained by expensive and often unaffordable professional development opportunities, such as obtaining a nursing degree. Oishi further notes that after the Caregiver Program, many migrant caregivers take on personal support worker (PSW) certifications because they are relatively inexpensive and enable migrant caregivers to work in nursing homes, retirement homes and hospitals. Pratt et al. (2008) note that migrant caregivers typically retain very few resources after the Caregiver Program because they are remitting large sums for family back home while also saving to bring their families to Canada if they obtain permanent residency.

\section{Asymmetrical accountability}

Migrant caregivers endure tremendous scrutiny in the Caregiver Program as well as through their process of immigration (Atanackovic \& Bourgeault, 2014). For example, in addition to government and employer requirements, Canay (2014) exposes employer surveillance in her narrative research study, noting how employers engage in observation of the migrant caregiver out of lack of trust and stereotypical attitudes contribute to an atmosphere of control for migrant caregivers. Additionally, there are asymmetrical stakes for migrant caregivers compared to their employers. Loss of employment and risk of deportation are enormous negative consequences for migrant caregivers who are terminated. Paling in comparison is the recourse when employers are abusive, who may endure fines or exclusion from the program. Regulatory protection asymmetrically favours the employers. Teeple Hopkins (2016) describes how migrant caregivers are only covered under labour law protections if they are employed through an agency in Quebec. Migrant caregivers paid by families have no protections under occupational health and safety acts, excluding them from Workers Compensation in the event of injury (Teeple Hopkins, 2016). Under federal government requirements of the Caregiver Program, employers are expected to provide third party health care insurance coverage for the first three months when migrant caregivers are ineligible for provincial insurance plans, but only $24 \%(n=21)$ did so according 
to Carlos and Wilson (2018). Galerand et al. (2015) reported a case where a migrant caregiver was charged expensive rent for their living accommodations. Furthermore, Atanackovic et al. (2014) described circumstances where accommodations did not meet federally mandated requirements, such as having a separate lockable space, but due to a lack of system checks there was no recourse.

\section{Social isolation}

Our analysis of social inclusion and integration would be remiss if we did not comment on the overwhelming social isolation that many migrant caregivers experience. Visas obtained under the Caregiver Program prohibit migrant caregivers from bringing family (Atanackovic et al., 2014). Many migrant caregivers endure long separations from their families which take a toll on their wellbeing. Tungohan (2012) also noted overwhelming disconnect from home life, particularly when they have maternal responsibilities at home. Parental obligations as primary caregivers, even while working abroad, generated high expectations for sustaining familial relationships with little control. According to Tungohan, gendered care work is reinforced when migrant caregivers transfer tasks to other female members within the household to cope.

Spitzer (2009) highlights the experience of migrant caregivers living in rural communities in Canada and exposes social isolation associated with constrained access to informal and formal social supports. She describes disruption in settlement and social integration when there is a paucity of social resources for migrant caregivers. Moreover, she notes a lack of autonomy and privacy when migrant caregivers have to rely on their employers for transport to health services, government offices, social gathering and religious services (Spitzer, 2009). Migrant caregiver who lived in smaller homogenous communities reported feeling subjugated by an Othering gaze (Spitzer, 2009). Rather than feeling included and having membership in the community, many described feelings of being exoticized and objectified (Spitzer, 2009).

\section{Resilience}

Resilience was an important theme that emerged from our analysis. Despite a lack of citizenship to enable active political participation such as voting, many migrant caregivers engaged through civil society activity, such as rallies and community engagement (Tungohan, 2012). Several authors noted gains through community activism that are relatively unexplored (Atanakovic et al., 2014; Bonifacio, 2008; Kapiga, 2009). Kapiga (2009) identified Filipino community groups as informational and emotional resources to facilitate migrant caregivers' connections to their culture, heritage and language, as well as engendering feelings of unity and belongingness. Organizations such as Filipino Solidarity Cooperative, the Industrial Welfare Commission (IWC) and PINAY (a Filipino word use to describe a Filipino woman living outside the Philippines) were listed as outlets to learn new skills, build confidence and develop social networks. Importantly, Kapiga identified collective organized resistance and inter-ethnic alliances as means to fight for rights and protections. These organizations play an important role in questioning power differentials and regulations that render migrant caregivers socially excluded. There is movement towards unionization among Caregiver Program advocates to address protection and bargaining rights (Kapiga, 2009). Root (2009) notes that the kinship garnered through informal support groups have mitigated symptoms of depression, homesickness and alienation. Furthermore, Root described how spirituality also plays a strong role for the survival of Filipina caregivers against isolation.

Tungohan (2012) illustrates the expansion of definitions of motherhood that ensues from migrant caregiving. While she highlights in depth the toll that transnational hyper-maternalism takes on migrant caregivers and their families, including traumatic family reunification, she also notes the resilience that is harvested when women come together. Specifically, she describes how support networks and counselling groups in host countries assist in challenging gendered norms and societal indifference. This type of advocacy is imperative to combat social exclusion.

\section{DISCUSSION}

The results of this scoping review illuminated systemic barriers for migrant caregivers to access equitable resources and rights to civic participation that support their wellbeing, including economic exploitation, deskilling and downward occupational 
mobility, asymmetrical accountability, and social isolation. These barriers produced and perpetuated a cycle of low-earning, lack of opportunity, and deskilling. The review also exposed the shortcomings of caregiver pathways for permanent residence geared towards settlement of newcomers over social integration compounded by social isolation. Finally, resilience emerged as a fifth theme to highlight community advocacy that exist despite exclusionary policies.

Parrenas (2001) defines 'partial citizen' as a migrant who lacks full integration in the destination country and yet also lacks protections in her country of origin. In Canada, immigrant pathways are built on settlement rather than integration which systematically undermines belonging. According to Parrenas (2001), migrant caregivers mitigate their partial citizenry by reasserting their belongingness to their home country. Childcare, senior care and care for persons with high medical needs continue to be under resourced within the public systems in Canada. Childcare, for example, is heavily reliant on informal supports such as relatives, unlicensed centers and home-daycares due to costs and waitlists (Hanley et al., 2017). Hanley et al. (2017) explain that commodified home-based, low-wage domestic work is encouraged through private markets, particularly in the absence of adequate national strategies and public policy. Furthermore, governments reinforce an informal care system through tax deductions to families in replacement of affordable care options. Underlying the lack of policy is a gendered value system, where men are traditionally visible as wage earners, while women are visible as mothers and occupy private spaces in the home (Crompton, 1999). Because of this value system, there is an enduring acceptance that caregiving is women's reproductive work, which renders it invisible and undervalued (Duffy, Albelda \& Hammonds, 2013). Instead of restructuring care work as legitimate, valued and skilled work, it has been shifted to racialized migrant caregivers - as low-wage and low-skilled work. Kelly, Astorga-Garcia, and Esguerra (2009) affirmed this trend in their mixed method study $(n=421)$ that found $66 \%$ of migrant caregivers experienced downward mobility and only $11 \%$ had found work analogous to their employment prior to leaving the Philippines. A lengthy separation from their profession practice coupled with erosion of their confidence associated with the confinement to unskilled labour contributed to deskilling (Zaman, 2006).
If care work continues to be low-paid or unpaid, asymmetrical accountability will persist. Indeed, reciprocal accountability was non-existent in many situations and became amplified when few or no channels ensured minimal protections for migrant caregivers (e.g., safeguards when policies were not followed by employers). Policy changes based on social justice are required to improve economic and social recognition of care work. Furthermore, movement towards government accountability for safe work environments is direly needed.

Low wages, third-party immigration fees and high remittance rates were all systemic mechanisms that reinforce economic exploitation among migrant caregivers, resulting in intricate power dynamics that sustain such exploitation. Bourgeault et al. (2010) reported how migrant caregivers are prohibited from seeking supplementary employment outside the residence of their employer through the Caregiver Program, and employers are free to terminate employment at any time. Furthermore, due to few employer regulations, the job description of migrant caregiver is often ambiguous, and caregivers are expected to serve in several capacities such as carers, cooks and entertainers. Because of precarious living status many migrant caregivers endure abuse and exploitation to maintain their employment (Atanackovic \& Bourgeault, 2014; Banerjee et al., 2017). Compounding the exploitation, there is underlying power system where most employers are middle and upper middle class and hold highly qualified jobs such as doctors, lawyers, professors, and engineers (Gallerand et al., 2015). Paradoxically, Bourgeault notes how the Caregiver Program promotes and exploits cheap labour that transcends economic echelons - particularly in a climate of unaffordable child and home care for many in Canada. Either way, migrant caregivers are filling a labour gap without protective regulation to ensure fairness of their work. Without adequate pay or protection, social integration is undermined particularly in a neoliberal system, like Canada, that equates worth predominantly with financial viability.

In 2011, G20 countries including Canada committed to reduce remittance fees paid to banks and transfer firms to $5 \%$ - which would result in an estimated \$11billion USD in the hands of families rather than banks worldwide (Westwood, 2013). Global Affairs Canada has partnered with Statistics 
Canada to conduct a survey to better gauge remittance rates. To date, Canada has not instituted regulations to meet the $5 \%$ target, Instead, migrant care work is the Wild West for unregulated employment recruitment agencies that capitalize on low-wage work, charge high fees and make false promises for permanent residency (PINAY, 2008). Their role becomes justified when government policy requires third-party agencies to legitimize care work and qualify for employment protections (Teeple Hopkins, 2016). Such perilous agencies would not be tolerated in high-earning sectors, or at the very least, there would be market controls to ensure fairness (i.e. charging employers for service rather than employees). Through restructuring, these agencies could channel opportunities for new employment, offer professional development and possible routes for unionization. Furthermore, these groups could take on advocacy work such as Canada falling short on its commitment to reduce remittance fees to $5 \%$, as part of its G20 promise (Westwood, 2013).

Despite a relative paucity of work, there was resounding consensus gleaned from the literature that migrant caregivers were relatively unprotected as employees. Indeed, this notion resonates with Salami, Amodu \& Okeke-Ihejirika (2016) study that found migrant caregivers were inadequately compensated and unable to afford housing outside of their employer's home, which compounded their fear to report incidents of abuse. Nursing professional associations could play an important role in advocating for equitable health conditions for these caregivers.

The social exclusion and lack of social protection experienced by migrant caregivers is largely structured by immigration policies. Specifically, initial migration to Canada as a temporary foreign worker impedes the social and economic integration of migrant caregivers. For instance, caregivers often have bachelor's degree before migrating to Canada, but they often work in unskilled jobs after the completion of the caregiver program (Kelly, AstorgaGarcia and Esguerra, 2009). Policy implications from our review indicate a need to expand permanent residence pathways for caregivers. Canada is one of a few countries that allows migrant workers to migrate initially as temporary foreign workers and then transition to permanent resident status. In Taiwan and Hong Kong, caregivers migrate as temporary foreign workers on a two-year contract and are unable to transition to permanent resident status
(Parrenas, 2001). In many other high-income countries (such as Australia and United States) specific pathways for migrant caregivers that includes initial temporary migration does not exist. Policy recommendations in Canada include the need to ensure migrant caregivers (including those providing child and elder care) can migrate to Canada as permanent resident.

A few considerations have been noted while interpreting findings from our scoping review. Firstly, while we adopted methodology by Levac et al. (2010) we have not shared our findings from this work with stakeholders. Including this step could offer unique insights and help refine some of the findings of this review. Furthermore, we were restricted in our access to certain academic journals and failure to include evidence from such journals may have omitted potentially valuable findings. Since the studies we accessed mainly represented English speaking migrant caregivers, we may be remiss in our depiction of social integration and inclusion for migrant caregivers who do not speak English.

\section{CONCLUSION}

This work invites critical discussion and promotes candid dialogue to inform policy changes to optimize social integration. Nurses must advocate for improving social conditions of migrant caregivers by addressing immigration policies that limits the social integration of migrant caregivers. This is especially important given that many migrant caregivers are nurses and many experience deskilling upon migration to Canada (Bourgeault et al., 2010; Kelly, Astorga-Garcia and Esguerra, 2009). Furthermore, it will be important to build on existing community work and resilience, while shifting away from settlement policies designed for short-term circumstances and move towards social integration, particularly given the high labour expectations on migrant caregivers.

\section{REFERENCES}

Arksey, H., \& O'Malley, L. (2005). Scoping studies: Towards a methodological framework. International Journal of Social Research Methodology, 8(1), 19-32. doi:10.1080/1364557032000119616

Atanackovic, J. \& Bourgeault, I. L. (2014). Economic and social integration of immigrant live-in caregivers in Canada. IRPP Study, No. 46. 
Retrieved from: http://irpp.org/wpcontent/uploads/assets/research/diversityimmigration-and-integration/atanackovicbourgeault-no46/study-no46.pdf

Bakan, A. B. \& Stasiulis, D. (2012). The political economy of migrant live-in caregivers: A case of unfree labour? In Patti Tamara Lenard and Christine Straehle (ed.), Legislated Inequality.

Banerjee, R., Kelly, P., Tungohan, E., GABRIELAOntario, Migrante-Canada, \& Community Alliance for Social Justice (CASJ) (2017). Assessing the Changes to Canada's Live-In Caregiver Program: Improving Security or Deepening Precariousness? Available: http://p2pcanada.ca/files/2017/12/Assessin g-the-Changes-to-Canadas-Live-InCaregiver-Program.pdf

Bonifacio, Glenda Lynna Anne Tibe. (2008). I care for you, who cares for me? transitional services of Filipino live-in caregivers in canada. Asian Women, 24(1), 25-50. doi:10.14431/aw.2008.03.24.1.25

Bourgeault, I. L., Atanackovic, J., LeBrun, J., Parpia, R., Rashid, A., Winkup, J. (2010) Immigrant care workers in aging societies: The Canadian context and experience, Ottawa, ON: Ontario Health Human Resource Research Network Retrieved from http://www.healthworkermigration.com/im ages/stories/docs/immigrant-care-workersreport-2.pdf.

Bourgeault, I. L., Parpia, R., \& Atanackovic, J. (2010). Canada's live-in caregiver program: Is it an answer to the growing demand for elderly care?. Journal of Population Ageing, 3(1-2), 83-102.

Carlos, J. K., \& Wilson, K. (2018). Migration among temporary foreign workers: Examining health and access to health care among Filipina live-in caregivers. Social Science \& Medicine, 209, 117-124. doi:10.1016/j.socscimed.2018.05.045

Canay, L. C. P. (2014). Clinging to a knife's edge: The live-in caregiver program

Castles, S. \& Miller, M.J. (2009). The age of migration: International population movements in the modern world. Journal of Contemporary European Research. 5(2).

Chowdhury, R., \& Gutman, G. (2012). Migrant live-in caregivers providing care to Canadian older adults: an exploratory study of workers' life and job satisfaction. Journal of Population Ageing, 5(4), 215-240.

Citizenship and Immigration Canada. (2009). News release: Minister Kenney proposes

significant improvement to the live-in caregiver program. Retrieved from http://www.cic.gc.ca.ezproxy.lib.ryerson.ca /english/department/media/releases/2009/ 2009-12-12.asp.

Cohen, R. (2000). "Mom is a stranger": The negative impact of immigration policies on the family life of Filipina domestic workers. Canadian Ethnic Studies, 32(3): 76-89.

Compton, R. (1999). The decline of male breadwinner: Explanations and interpretations in Restructuring gender relations and employment: The decline of the male breadwinner, edited by R. Crompton. Oxford and New York: Oxford University Press.

D'Addario, S. (2013). Finding home: Geographical links between paid and unpaid work for transnational care workers in Toronto's suburbs. https://www.library.yorku.ca/find/Record/3 207843

Duffy, M., Albelda, R., \& Hammonds, C. (2013). Counting care work: The empirical and policy applications of care theory. Social Problems. 60(2):145-167.

Galerand, E., Gallie, M., \& Gobeil, J. O. (2015). Domestic labour and exploitation: The case of the live-in caregiver program (LCP) in Canada. SAC-PINAY Research Report. Retrieved from: http://www.mcgill.ca/lldrl/ labour-law-and-development-research laboratory.

Hanley, J., Larios, L., \& Koo, J.H. (2017). Does Canada "care" about migrant caregivers? Implications under the reformed caregiver program. Canadian Ethnic Studies, 49(2), 121-139. doi: http://doi.org/10.1353/ces.2018.0015

Hochschild, A. R. (2002). Love and gold. Global women: Nannies, maids and sex workers in the new economy. Eds. Barbara Ehrenreich and Arlie Russell Hochschild. New York: Henry Holt and Company. 14-30.

Kapiga, I. (2009). Agents of change, colours of resistance: The socio-economic integration of Filipina live-in caregivers in Montreal. 
International Health Trends and Perspectives

(Doctoral dissertation, Concordia University).

Kelly, P., Astorga-Garcia, M., Esguerra, E. F., \& Community Alliance for Social Justice.

(2009). Explaining the deprofessionalized Filipino: Why Filipino immigrants get low paying jobs in Toronto (CERIS Working Paper No. 75). Toronto, ON: Joint Centre of Excellence on Research on Immigration and Settlement.

Kelly, P., Park, S., de Leon, C., Priest, J. (2011). Profile of live-in caregiver immigrants to

Canada, 1993-2009. Toronto Immigration Employment Data Initiative (TIEDI) Analytical Report 18.

Levac, D., Colquhoun, H., \& O'Brien, K. K. (2010). Scoping studies: Advancing the methodology. Implementation Science: IS, 5(1), 69-69. doi:10.1186/1748-5908-5-69.

Migrant Workers Alliance for Change (2017). Repeal Section 38(1)(c). Retrieved from: http://www.migrantworkersalliance.org/pol icy-submission-repeal-section-381c-of-irpa/

Migrant Workers Alliance for Change (2018). What's happening with the caregiver program? Retrieved from: http://www.migrantworkersalliance.org/wp -content/uploads/2018/02/20180222_Infoflyer-for-Caregivers-on-2019-expiry.pdf

Miller, M. (2011). Claiming a life of permanence: Filipina caregivers' migration experiences in Canada's live-in caregiver program. Montreal: McGill University. Retrieved from: https://www.proquest.com/docview/87396 6867. Accessed September 142020.

Oishi, N. (2008). Population Aging and Migration: Migrant Workers in Elder Care in Canada. The Journal of Social Science, (65), 103-122.

Palmer, K. S. (2010). Spaces of belonging: Filipina LCP migrants and their practice of claiming space in Toronto. Master of Arts in Geography Thesis: University of Toronto. Retrieved from:

https://tspace.library.utoronto.ca/bitstrea m/1807/24614/3/Palmer_Katelyn_S_20106 _MA _thesis.pdf. Accessed September 14, 2020.

Parreñas, R. S. (2001). "The International Division of Reproductive Labor," pp. 61-79, in Parreñas, R. S., Servants of Globalization: Women, Migration, and Domestic Work. Stanford: Stanford University Press

Parreñas, R. S. (2012). The reproductive labour of migrant workers. Global Networks. 12(2): 269-275.

Parreñas, R. S., Silvey, R., Hwang, M.C. (2015). Serial labour migration: Precarity and itinerancy among Filipino and Idonesian domestic workers. International Migration Review. https://doi.org/10.1177/019791831880476 9.

PINAY, 2008, Warning! Domestic work can be dangerous to your immigration status, health, safety and wallet, Report on the finding of a community-based survey of work condition of Montreal domestic workers. Montreal, online: https://docs.google.com/file/d/1PINzXgoxD vSX3ZP9Ua44M6Zoy_blrwfgzdUFHOcwLjJxsmGsUo2wEQBRwj6/edit?hl=en

Pratt, G., Pendakur, R., Ugnayan ng Kabataang Pilipino sa Canada, Philippine Women Centre of B.C, \& Metropolis British Columbia. Centre of Excellence for Research on Immigration and Diversity. (2008). Deskilling across the generations: Reunification among transnational Filipino families in Vancouver Metropolis British Columbia, Centre of Excellence for Research on Immigration and Diversity.

Root, L. (2008). "I may be lost but I know how to find my way.": The 'lived' experiences of

Filipina caregivers in the live-in caregivers' program in Halifax. Masters Thesis, Mount Saint Vincent University.

Salami, O. O. (2014). "All for the family": A case study on the migration of Philippine educated nurses to Ontario through the live-in caregiver program (Doctoral dissertation).

Salami, B. (2016). Migrant nurses and federal caregiver programs in Canada: Migration and health human resources paradox. Canadian Journal of Nursing, 48(2), 35-40. doi: 10.1177/0844562116663951

Salami, B., \& Nelson, S. (2014). The downward occupational mobility of internationally educated nurses to domestic workers. Nursing Inquiry, 21(2), 153-161. doi:10.1111/nin.12029

Salami, B., Amodu, O., \& Okeke-Ihejirika, P. (2016). Migrant nurses and care workers rights in 
Canada (No. 2016-9). UNRISD Working Paper.

Spitzer, D. L., Prairie Metropolis Centre, \& Prairie Centre of Excellence for Research on Immigration and Integration. (2009). Live-in caregivers in rural and small city Alberta Prairie Metropolis Centre.

Spitzer, D. L., Torres, S., Doucet, M. J., CERIS, \& Ontario Metropolis Centre. (2008). Genderbased barriers to settlement and integration for live-in-caregivers: A review of the literature CERIS - The Ontario Metropolis Centre.

Stasiulis, D. K. \& Bakan, A. B. (2005). Negotiating citizenship: Migrant women in Canada and the global system. Toronto, Ontario: University of Toronto Press.

Tastsoglou, E., \& Dobrowolsky, A. (2017). Gender and care relationships in transnational families: Implications for citizenship and belonging. Canadian Ethnic Studies, 49(3), 111-113. doi:10.1353/ces.2017.0024

Teeple Hopkins, C. (2017). Work intensifications, injuries and legal exclusions for paid domestic workers in Montréal, Québec. Gender, Place \& Culture, 24(2), 201-212. doi:10.1080/0966369X.2017.1298573

Tungohan, E. (2013). Reconceptualizing motherhood, reconceptualizing resistance: Migrant domestic workers, transnational hyper maternalism and activism. International Feminist Journal of Politics, 15(1), 39-57. doi:10.1080/14616742.2012.699781

Tungohan, E., Banerjee, R., Chu, W., Cleto, P., de Leon, C., Garcia, M.,...Sorio, C. (2015). After the live-in caregiver program: Filipina caregivers' experiences of graduated and uneven citizenship. Canadian Ethnic Studies, 47(1), 87-105. doi: http://doi.org/10.1353/ces.2015.0008

Walton-Roberts, M., \& Hennebry, J. (2012). Indirect pathways into practice: A comparative examination of Indian and Philippine internationally educated nurses and their entry into Ontario's nursing profession. CERIS Working Paper Series 92. Toronto, Ontario.

Westwood, R. (2013). Should Canada make it easier for immigrants to send money home? Maclean's Magazine. Retrieved from: http://www2.macleans.ca/2013/02/19/ho meward-bound-2/remittances/
Zaman, H. (2006). Breaking the iron wall: Decommodification and immigrant women's labour in Canada. Lanham, MD: Lexington Books. 
Figure 1: Inclusion/Exclusion Criteria

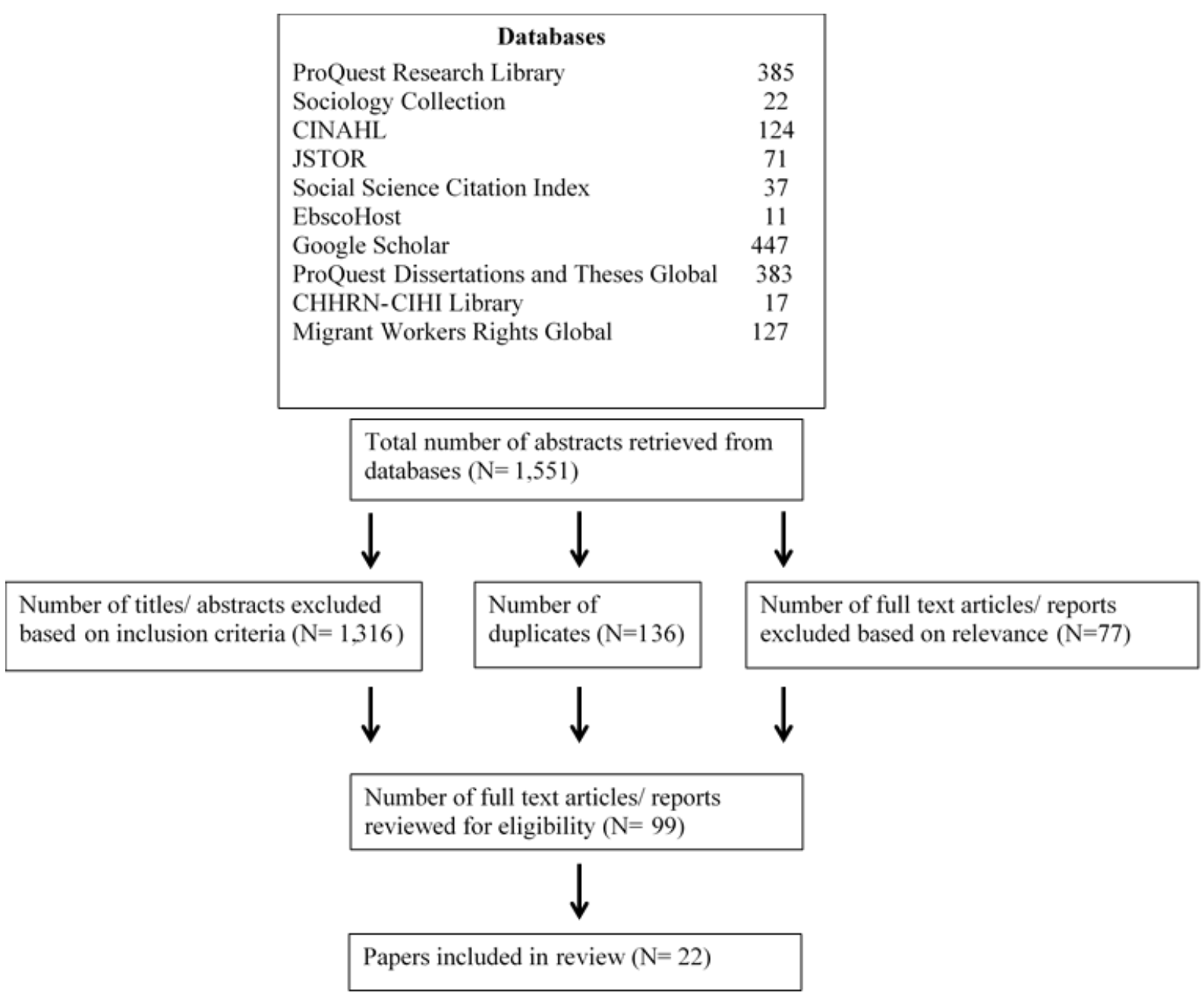


Table 1: Inclusion/Exclusion Criteria

\begin{tabular}{|l|l|}
\hline Inclusion & $\begin{array}{l}\text { Population: Former or current members of the migrant caregiver program; age 18+, women, migrants in Canada } \\
\text { Type of articles: primary and secondary source peer-reviewed articles, English language between 2001-2020 }\end{array}$ \\
\hline Exclusion & $\begin{array}{l}\text { Population: members of the temporary foreign workers program - not in the migrant caregiver program; age less than 18, males, migrants } \\
\text { not in Canada }\end{array}$
\end{tabular}


Table 2: Study Results

\begin{tabular}{|c|c|c|c|c|c|}
\hline Citation & Location & Study Objectives & Participant Sample & Study Design & Major Findings \\
\hline Bonifacio, 2008 & $\begin{array}{l}\text { Southern } \\
\text { Alberta }\end{array}$ & $\begin{array}{l}\text { To explore the transitional supports and services } \\
\text { used by migrant caregivers while in the Live-In } \\
\text { Caregiver Program and services provided by the } \\
\text { Philippine government during this period. }\end{array}$ & $\begin{array}{l}30 \text { Filipino live-in } \\
\text { caregivers. }\end{array}$ & $\begin{array}{l}\text { Qualitative: } \\
\text { Interviews and focus } \\
\text { group discussions } \\
\text { between 2006-2007. }\end{array}$ & $\begin{array}{l}\text { Economic } \\
\text { exploitation } \\
\text { Asymmetrical } \\
\text { accountability } \\
\text { Social isolation }\end{array}$ \\
\hline $\begin{array}{l}\text { Bourgealt, Parpia \& } \\
\text { Atankovic, } 2010\end{array}$ & $\begin{array}{l}\text { Hamilton, } \\
\text { Toronto, } \\
\text { Vancouver, } \\
\text { Victoria, } \\
\text { Montreal }\end{array}$ & $\begin{array}{l}\text { To contribute knowledge about the experiences } \\
\text { of live-in caregivers and perceptions of their } \\
\text { relationships with clients and their families. }\end{array}$ & $\begin{array}{l}19 \text { immigrant care } \\
\text { workers who came to } \\
\text { Canada through LCP who } \\
\text { were presently working in } \\
\text { a range of different health } \\
\text { care institutions: large/ } \\
\text { small institutional } \\
\text { settings, home services } \\
\text { and private households. }\end{array}$ & $\begin{array}{l}\text { Qualitative: Semi- } \\
\text { structured interviews } \\
\text { and two focus groups } \\
\text { between 2007-2008. }\end{array}$ & $\begin{array}{c}\text { Economic } \\
\text { exploitation } \\
\text { Downward } \\
\text { occupational mobility } \\
\text { Social isolation }\end{array}$ \\
\hline $\begin{array}{l}\text { Chowdhury \& } \\
\text { Gutman, } 2012\end{array}$ & $\begin{array}{l}\text { British } \\
\text { Columbia }\end{array}$ & $\begin{array}{l}\text { To further understanding of services provided by } \\
\text { LCP elder care workers, the nature of employer- } \\
\text { employee relations, as well as their experiences } \\
\text { and perceptions as migrant care workers. } \\
\text { To understand the job trajectory and life/ job } \\
\text { satisfaction of LCP elder care workers. }\end{array}$ & $\begin{array}{c}14 \text { migrant LCP-LTC }{ }^{1} \\
\text { workers (13 Filipino) in } \\
2009 \\
5 \text { migrant LCP-LTC } \\
\text { workers in } 2011 \text { before, } \\
\text { during, and after working } \\
\text { under LCP. }\end{array}$ & $\begin{array}{l}\text { Mixed methods: Face- } \\
\text { to-face interviews, } \\
\text { job satisfaction scale. }\end{array}$ & $\begin{array}{l}\text { Social isolation } \\
\text { Resilience }\end{array}$ \\
\hline Kapiga, 2009 & $\begin{array}{l}\text { Montreal, } \\
\text { Quebec }\end{array}$ & $\begin{array}{l}\text { To explore the influence of the LCP on the socio- } \\
\text { economic integration and personal experiences } \\
\text { of a sample of Filipina live-in caregivers using an } \\
\text { anti-racist, feminist approach. }\end{array}$ & $\begin{array}{l}31 \text { Filipina live-in } \\
\text { caregiver women. }\end{array}$ & $\begin{array}{c}\text { Qualitative: Semi } \\
\text { structured interviews. }\end{array}$ & $\begin{array}{l}\text { Asymmetrical } \\
\text { accountability } \\
\text { Social isolation } \\
\text { Resilience }\end{array}$ \\
\hline Miller, 2010 & $\begin{array}{l}\text { Montreal, } \\
\text { Quebec }\end{array}$ & $\begin{array}{l}\text { To explore some of the challenges experienced } \\
\text { by Filipina caregivers in the LCP; barriers faced in }\end{array}$ & $\begin{array}{l}15 \text { Filipino LCP caregivers, } \\
3 \text { community organization }\end{array}$ & $\begin{array}{l}\text { Qualitative: In-depth } \\
\text { semi-structured }\end{array}$ & $\begin{array}{l}\text { Economic } \\
\text { exploitation }\end{array}$ \\
\hline
\end{tabular}

${ }^{1}$ Long-term Care (LTC) 


\begin{tabular}{|c|c|c|c|c|c|}
\hline & & $\begin{array}{l}\text { confronting these challenges; why some } \\
\text { caregivers claim their rights; and strategies that } \\
\text { migrant caregivers in the LCP use to overcome } \\
\text { barriers to accessing rights. }\end{array}$ & $\begin{array}{c}\text { workers and } 2 \\
\text { government employees. }\end{array}$ & $\begin{array}{l}\text { interviews between } \\
\text { 2009-2010. }\end{array}$ & $\begin{array}{l}\text { Downward } \\
\text { occupational mobility } \\
\text { Asymmetrical } \\
\text { accountability } \\
\text { Social isolation } \\
\text { Resilience }\end{array}$ \\
\hline Oishi, 2008 & $\begin{array}{l}\text { Toronto, } \\
\text { Ontario }\end{array}$ & $\begin{array}{l}\text { To analyze the experiences of migrant elder } \\
\text { caregivers under LCP, their working conditions, } \\
\text { how they exercise their rights, and the economic } \\
\text { integration process after LCP. }\end{array}$ & $\begin{array}{l}40 \text { Filipino migrant care } \\
\text { workers, } 27 \text { government } \\
\text { officials/ recruitment } \\
\text { agency representatives/ } \\
\text { employers/ } \text { NGO }^{2} \\
\text { representatives. }\end{array}$ & $\begin{array}{l}\text { Qualitative: In-depth } \\
\text { interviews between } \\
\text { 2005-2007. }\end{array}$ & $\begin{array}{c}\text { Economic } \\
\text { exploitation } \\
\text { Downward } \\
\text { occupation mobility } \\
\text { Social isolation }\end{array}$ \\
\hline Palmer, 2010 & $\begin{array}{l}\text { Toronto, } \\
\text { Ontario }\end{array}$ & $\begin{array}{l}\text { To understand how Filipina LCP migrants cope } \\
\text { with their experiences of exclusion at various } \\
\text { scales across Toronto. To explore some of the } \\
\text { key sites and spaces of the social networks of } \\
\text { Filipina LCP migrants. To enrich the } \\
\text { understanding of the global care chains model by } \\
\text { drawing attention to the coping practices of } \\
\text { Filipina LCP migrants in their efforts to create } \\
\text { communities of affirmation, care, and belonging. }\end{array}$ & $\begin{array}{l}30 \text { Filipina LCP migrants } \\
\text { for young children. }\end{array}$ & $\begin{array}{l}\text { Qualitative: Semi- } \\
\text { structured in-depth } \\
\text { interviews and } \\
\text { participant } \\
\text { observation between } \\
\text { February 2009-May } \\
2009 .\end{array}$ & $\begin{array}{l}\text { Social isolation } \\
\text { Asymmetrical } \\
\text { accountability } \\
\text { Resilience }\end{array}$ \\
\hline PINAY, 2008 & $\begin{array}{l}\text { Vancouver, } \\
\text { British } \\
\text { Columbia }\end{array}$ & $\begin{array}{l}\text { To argue that the LCP sets the course for families' } \\
\text { lives in Canada, by drawing all of the family } \\
\text { members into its orbit of social exclusion. }\end{array}$ & $\begin{array}{l}27 \text { Filipino families who } \\
\text { have lived through the } \\
\text { LCP experience. }\end{array}$ & $\begin{array}{l}\text { Qualitative: } \\
\text { Interviews between } \\
\text { 2004-2008. }\end{array}$ & $\begin{array}{c}\text { Economic } \\
\text { exploitation } \\
\text { Downward } \\
\text { occupational mobility } \\
\text { Asymmetrical } \\
\text { accountability }\end{array}$ \\
\hline
\end{tabular}

$\overline{{ }^{2} \text { Non-Government Organization (NGO) }}$ 


\begin{tabular}{|c|c|c|c|c|c|}
\hline Pratt et al. (2009) & $\begin{array}{l}\text { Vancouver, } \\
\text { British } \\
\text { Columbia }\end{array}$ & $\begin{array}{l}\text { To argue that rather than reunification ending } \\
\text { the LCP experience, the LCP sets the course for } \\
\text { families' lives in Canada, by drawing all of the } \\
\text { family members into its orbit of social exclusion }\end{array}$ & $\begin{array}{l}27 \text { Filipino families who } \\
\text { have lived through the } \\
\text { LCP experience }\end{array}$ & $\begin{array}{l}\text { Qualitative interviews } \\
\qquad(2004-2008)\end{array}$ & $\begin{array}{l}\text { Downward } \\
\text { occupational mobility } \\
\text { Social isolation }\end{array}$ \\
\hline Root, 2008 & $\begin{array}{l}\text { Halifax, } \\
\text { Nova Scotia }\end{array}$ & $\begin{array}{c}\text { To explore the lived experiences of domestic } \\
\text { workers/ caregivers who live in a small, or } \\
\text { medium sized urban centre with lower levels of } \\
\text { cultural and racial diversity. }\end{array}$ & $\begin{array}{l}5 \text { Filipino migrant } \\
\text { caregivers ( } 3 \text { with children } \\
\text { residing in Philippines and } \\
\quad 2 \text { single) }\end{array}$ & $\begin{array}{l}\text { Qualitative: In-depth } \\
\text { interviews. }\end{array}$ & $\begin{array}{l}\text { Economic } \\
\text { exploitation } \\
\text { Social isolation }\end{array}$ \\
\hline Spitzer, 2009 & $\begin{array}{l}\text { Rural and } \\
\text { small city } \\
\text { Alberta }\end{array}$ & $\begin{array}{l}\text { To highlight the experiences of live-in caregivers } \\
\text { currently working and living in Alberta outside } \\
\text { major urban centres, illuminate the working } \\
\text { conditions of migrant caregivers and examine } \\
\text { access to social supports or health services. }\end{array}$ & $\begin{array}{l}39 \text { live-in caregivers (38 } \\
\text { from Philippines, } 1 \text { from } \\
\text { India). } \\
224 \text { surveys sent to } \\
\text { immigrant serving } \\
\text { agencies, extended care } \\
\text { facilities, hospitals, } \\
\text { religious institutions, } \\
\text { service organizations. }\end{array}$ & $\begin{array}{c}\text { Mixed methods. } \\
\text { Qualitative: } \\
\text { Interviews and focus } \\
\text { groups. } \\
\text { Quantitative: Survey } \\
\text { of local institutions } \\
\text { and organizations. }\end{array}$ & $\begin{array}{c}\text { Economic } \\
\text { exploitation } \\
\text { Downward } \\
\text { occupational mobility } \\
\text { Social isolation }\end{array}$ \\
\hline Tungohan, 2013 & $\begin{array}{l}\text { Toronto, } \\
\text { Ontario }\end{array}$ & $\begin{array}{l}\text { To illustrate how migrant caregivers negotiate } \\
\text { their maternal responsibilities from afar and how } \\
\text { those responsibilities inform their political } \\
\text { activities in Canada. }\end{array}$ & $\begin{array}{l}15 \text { Filipino live-in } \\
\text { caregivers. }\end{array}$ & $\begin{array}{l}\text { Qualitative: Semi- } \\
\text { structured interviews } \\
\text { in } 2010 .\end{array}$ & $\begin{array}{l}\text { Social isolation } \\
\text { Resilience }\end{array}$ \\
\hline Tungohan et al., 2015 & $\begin{array}{c}\text { Canada } \\
\text { (FG: } \\
\text { Montreal, } \\
\text { Toronto, } \\
\text { Ottawa, } \\
\text { Calgary, } \\
\text { Edmonton, } \\
\text { Vancouver) }\end{array}$ & $\begin{array}{l}\text { This study examined the economic, social, and } \\
\text { structural barriers involved in the transition from } \\
\text { the LCP to the Canadian labour market. }\end{array}$ & $\begin{array}{l}\text { Former live-in caregivers } \\
\text { (survey respondents } \\
\qquad \mathrm{N}=631 \text { ). }\end{array}$ & $\begin{array}{l}\text { Mixed methods: } \\
\text { Focus group } \\
\text { interviews, national } \\
\text { survey data }\end{array}$ & $\begin{array}{c}\text { Economic } \\
\text { exploitation } \\
\text { Downward } \\
\text { occupational mobility } \\
\text { Asymmetrical } \\
\text { accountability }\end{array}$ \\
\hline Banerjee et al., 2017 & $\begin{array}{l}\text { Canada (FG: } \\
\text { Toronto, } \\
\text { Montreal, } \\
\text { Vancouver, } \\
\text { Calgary, } \\
\text { Edmonton, } \\
\text { Ottawa) }\end{array}$ & $\begin{array}{l}\text { This report summarizes the findings of studies on } \\
\text { former LCP caregivers transitioning from the } \\
\text { precarious role of temporary foreign workers to } \\
\text { permanent Canadian citizens. }\end{array}$ & $\begin{array}{l}\text { Former live-in caregivers } \\
\text { (survey respondents } \\
\qquad \mathrm{N}=631 \text { ). }\end{array}$ & $\begin{array}{l}\text { Mixed methods: } \\
\text { Focus group } \\
\text { interviews, national } \\
\text { survey data }\end{array}$ & $\begin{array}{c}\text { Economic } \\
\text { exploitation } \\
\text { Downward } \\
\text { occupational mobility }\end{array}$ \\
\hline
\end{tabular}




\begin{tabular}{|c|c|c|c|c|c|}
\hline & & & & & $\begin{array}{l}\text { Asymmetrical } \\
\text { accountability } \\
\text { Social isolation }\end{array}$ \\
\hline $\begin{array}{c}\text { Tastsoglou \& } \\
\text { Dobrowolsky, } 2017\end{array}$ & $\begin{array}{l}\text { Canada } \\
\text { (Halifax, } \\
\text { Nova Scotia) }\end{array}$ & $\begin{array}{l}\text { This study explored the influence of gender } \\
\text { politics on transnational care relations and } \\
\text { practices of permanent residents and foreign- } \\
\text { born citizens. }\end{array}$ & $\begin{array}{c}\text { Racially diverse } \\
\text { newcomers who have } \\
\text { been/were involved in } \\
\text { transnational caregiving } \\
\text { within the last } 5 \text { years } \\
\text { ( } \mathrm{N}=20 ; 8 \text { men, } 12 \\
\text { women). }\end{array}$ & $\begin{array}{l}\text { Qualitative: Semi- } \\
\text { structured in-depth } \\
\text { interviews }\end{array}$ & $\begin{array}{l}\text { Asymmetrical } \\
\text { accountability } \\
\text { Social isolation }\end{array}$ \\
\hline $\begin{array}{c}\text { Atanackovic \& } \\
\text { Bourgeault, } 2014\end{array}$ & $\begin{array}{l}\text { Canada } \\
\text { (Quebec, } \\
\text { Ontario, } \\
\text { British } \\
\text { Columbia) }\end{array}$ & $\begin{array}{l}\text { This study assessed economic and social } \\
\text { integration of live-in caregivers while employed } \\
\text { in the LCP, after the } 2010 \text { policy changes, and } \\
\text { beyond completion of the program. }\end{array}$ & $\begin{array}{l}\text { Current and former } \\
\text { migrant care workers } \\
\text { involved in older adult } \\
\text { care }(\mathrm{N}=27) \text {, child care } \\
(\mathrm{N}=28) \text {, or both }(\mathrm{N}=3) .\end{array}$ & $\begin{array}{l}\text { Qualitative: In-depth } \\
\text { interviews and focus } \\
\text { groups }\end{array}$ & $\begin{array}{c}\text { Economic } \\
\text { exploitation } \\
\text { Downward } \\
\text { occupational mobility } \\
\text { Asymmetrical } \\
\text { accountability } \\
\text { Social isolation }\end{array}$ \\
\hline Salami, 2014 & $\begin{array}{l}\text { Canada } \\
\text { (Toronto, } \\
\text { Ontario) }\end{array}$ & $\begin{array}{l}\text { This study explored the experiences of foreign- } \\
\text { trained nurses who migrate to Ontario through } \\
\text { the LCP. }\end{array}$ & $\begin{array}{l}\text { Nurses who migrated to } \\
\text { Canada through the LCP } \\
\qquad(\mathrm{N}=14) .\end{array}$ & $\begin{array}{l}\text { Qualitative: Case } \\
\text { study methodology, } \\
\text { in-depth interviews }\end{array}$ & $\begin{array}{c}\text { Downward } \\
\text { occupational mobility } \\
\text { Social isolation } \\
\\
\text { Economic } \\
\text { exploitation }\end{array}$ \\
\hline $\begin{array}{l}\text { Galerand, Gallié, \& } \\
\text { Gobeil, } 2015\end{array}$ & Canada & $\begin{array}{l}\text { This study explored the effects of exploitative } \\
\text { labour laws and conditions faced by caregivers } \\
\text { employed through the LCP. }\end{array}$ & $\begin{array}{l}\text { Domestic workers who } \\
\text { had been submitted to } \\
\text { the live-in requirements } \\
\text { during } 24 \text { months as } \\
\text { provided by the LCP } \\
(\mathrm{N}=33) .\end{array}$ & $\begin{array}{l}\text { Mixed methods: } \\
\text { questionnaire, semi- } \\
\text { structured interviews }\end{array}$ & $\begin{array}{c}\text { Economic } \\
\text { exploitation } \\
\text { Downward } \\
\text { occupational mobility } \\
\text { Social isolation }\end{array}$ \\
\hline $\begin{array}{c}\text { Carlos \& Wilson, } \\
2018\end{array}$ & $\begin{array}{l}\text { Canada } \\
\text { (Greater } \\
\text { Toronto }\end{array}$ & $\begin{array}{l}\text { This study examined the physical and mental } \\
\text { health of migrant caregivers employed through } \\
\text { the LCP. }\end{array}$ & $\begin{array}{l}\text { Women born in the } \\
\text { Phillipines who came to } \\
\text { Canada under the LCP }\end{array}$ & $\begin{array}{l}\text { Qualitative: Semi- } \\
\text { structured interviews }\end{array}$ & $\begin{array}{l}\text { Asymmetrical } \\
\text { accountability }\end{array}$ \\
\hline
\end{tabular}


International Health Trends and Perspectives

\begin{tabular}{|c|c|c|c|c|c|}
\hline & $\begin{array}{c}\text { Area, } \\
\text { Ontario) }\end{array}$ & & $\begin{array}{l}(\mathrm{N}=23) \text {; current live-in } \\
\text { caregivers }(\mathrm{N}=4) \text { and } \\
\text { former live-in caregivers } \\
(\mathrm{N}=17) \text {. }\end{array}$ & & Social isolation \\
\hline Teeple Hopkins, 2016 & $\begin{array}{c}\text { Canada } \\
\text { (Montreal, } \\
\text { Quebec) }\end{array}$ & $\begin{array}{c}\text { This study assessed how work intensification, } \\
\text { workplace injury, and structural exclusion from } \\
\text { labour laws affect paid domestic workers in } \\
\text { Canada. }\end{array}$ & $\begin{array}{l}\text { Paid domestic workers, } \\
\text { aged } 18-65, \text { legally } \\
\text { residing in Montreal; } \\
\text { migrant live-in caregivers } \\
(\mathrm{N}=3) \text { or other domestic } \\
\text { worker }(\mathrm{N}=1) \text {. }\end{array}$ & $\begin{array}{l}\text { Qualitative: In-depth } \\
\text { interviews }\end{array}$ & $\begin{array}{l}\text { Economic } \\
\text { exploitation } \\
\text { Social isolation }\end{array}$ \\
\hline Canay, 2014 & $\begin{array}{c}\text { Canada } \\
\text { (Toronto, } \\
\text { Ontario) }\end{array}$ & $\begin{array}{l}\text { This study explored Filipina women's experiences } \\
\text { with the LCP in Toronto, Canada. }\end{array}$ & $\begin{array}{l}\text { Individuals with a "live-in" } \\
\text { experience under the LCP, } \\
\text { who identify as Filipina, } \\
\text { age } 30-64 \text { years old, have } \\
\text { recently completed the } \\
\text { program } 1-3 \text { years ago } \\
(\mathrm{N}=3) .\end{array}$ & $\begin{array}{l}\text { Qualitative: } \\
\text { Unstructured, open- } \\
\text { ended interviews }\end{array}$ & $\begin{array}{l}\text { Economic } \\
\text { exploitation } \\
\text { Social isolation }\end{array}$ \\
\hline $\begin{array}{l}\text { Walton-Roberts et al } \\
\text { (2012) }\end{array}$ & Ontario & $\begin{array}{l}\text { To examine the experiences of nurses entering } \\
\text { Ontario as temporary migrants through LCP and } \\
\text { as international students who convert to } \\
\text { permanent status and re-enter the nursing } \\
\text { profession. What are the pathways (re-training, } \\
\text { language training, etc.) these nurses take to gain } \\
\text { re-entry into the profession? What are the } \\
\text { impacts of this emerging "temp-to-perm" model } \\
\text { of migration, on the nursing sector, and on } \\
\text { immigrant social and economic integration? }\end{array}$ & $\begin{array}{l}30 \text { Nurses from the } \\
\text { Philippines in Ontario } \\
\text { under the LCP } \\
\text { AND } \\
68 \text { Nurses from India } \\
\text { entering Ontario colleges } \\
\text { as international students }\end{array}$ & $\begin{array}{l}\text { Qualitative (semi- } \\
\text { structured interviews) } \\
\text { and quantitative } \\
\text { (surveys) } \\
2 \text { sets of case study } \\
\text { groups }\end{array}$ & $\begin{array}{c}\text { Downward } \\
\text { occupational mobility }\end{array}$ \\
\hline
\end{tabular}

